\title{
Effectiveness of Regional Protection Program (RPP) Rezim - International Protection Regime - European Union (EU) in Germany
}

\author{
Hamza Fadil (Corresponding Author) \\ Department of Sociology, School of Public Administration Hohai University \\ Focheng West Road, Nanjing, China \\ E-mail: h-fadil@hotmail.com
}

Shen Yi

Department of Sociology, School of Public Administration Hohai University

Focheng West Road, Nanjing, China

Received: Jul. 23, 2019 Accepted: Oct. 24, 2019 Online published: Nov. 15, 2019

doi:10.5296/jpag.v9i4.15830 URL: https://doi.org/10.5296/jpag.v9i4.15830

\begin{abstract}
Refugees migrate from their countries to other countries in the study of migration because of natural disasters, famine, difficulty in getting jobs, and fear of war or armed conflict in their countries. The problem of the Syrian refugee crisis in 2011 due to armed conflict made Syrian refugees leave their country for Europe. In 2011 Syrian refugees began to enter Europe through waters, then UNHCR announced the status of refugees and encouraged the EU to respond with refugee acceptance. In 2012 the EU then adopted the Regional Protection Program - International protection regime in accepting refugees. Germany was then very enthusiastic in accepting refugees, so there were many refugee destinations to get protection. Through the German resettlement scheme then received many refugees. Through the Balkan lane the EU then negotiated with Turkey which made it easier for refugees to enter Europe, then it had implications for the increasing number of refugees entering Europe in 2015. This caused fears of the Balkan countries so that the peak of the Balkan lane was closing which resulted in a reduction in German revenue from the original plan of acceptance. Therefore, the author wants to confirm whether the Regional Protection Program - International protection regime is quite effective in carrying out the reception of Syrian refugees in 2013-2015. The writer uses Arild Uderdal's regime effectiveness concept, which consists of
\end{abstract}


several variables such as problem type, problem-solving capacity, and the level of collaboration then to confirm the effectiveness of this regime.

Keywords: Syrian refugee crisis, resettlement, regional protection program, international protection regime, EU, Germany, Balkan path, concept of regime effectiveness

\section{Introduction}

The cause of a citizen to migrate from his country to another country is due to several factors, namely natural disasters, hunger, difficulty finding work, or because of the fear of war that threatens their safety. The refugees leave their home countries to get a safe and comfortable place to live. Refugees do not get guarantees of protection by their home country so citizens must leave their country. Therefore, the protection of aid to them becomes the responsibility of the international community on behalf of humanity and the protection of human rights. The problem of the Syrian refugee crisis to Europe which has increased since the rise of the Arab Spring in 2011 has triggered the problematic crisis of countries in the Middle East region, one of which is Syria. The armed conflict intervened both the government, militants and the rise of ISIS militant organizations pushing Syria's domestic conditions into armed conflict over protests to the Government of President Bashar Al-Assad demanding his resignation.

The European Union is a supra-national organizational entity and is one of the main instruments in responding to the Syrian crisis. The European Union has the responsibility to manage refugees with their member states and non-EU countries. 14 June 2004 EU communication commission proposes new EU approach to create International Protection Regime. Regional Protection Program (RPP) was then proposed as a solution to realize the International Protection Regime's protection capacity in regional areas which is better in protecting refugees coming to Europe and its population (COMISSION OF THE EUROPEAN COMMUNITIES, 2005). The RPP provides protection for the EU resettlement scheme which provides protection for every refugee who comes to EU territory. RPP is a form of Regional Protection Regime which is more effective, as said by Samuel Barkin that the regime of behavioral effects of international organizations on other actors, especially countries that have a set of principles, norms, rules and procedures in making decisions that affect actors who gather around issue (Barkin, 2005). The RPP has rules for each member to then fulfill the annual quota.

Each member is an EU member state which later became part of this regime. In fulfilling quotas, the RPP stipulates regulations to fulfill quotas in accepting refugees. The acceptance and fulfillment of this quota is then left to each country in its fulfillment, this fulfillment is applied voluntarily to each of its member countries (COMMISSION OF THE EUROPEAN COMMUNITIES, 2005). The RPP has norms and procedures for accepting refugees, which see the purpose of this RPP to then protect the region and provide a place for refugees. With the aim of improving the management of refugee flows and increasing refugee protection capacity in many EU refugee areas, thereby increasing cooperation with non-EU countries to realize a long-term resettlement solution, to make this cooperation a reality the European Commission makes the EU Regional Protection Programs and Resettlement Schemes (RPP) 
(European Commission, 2012).

The European Commission submitted a proposal for an EU resettlement scheme to the Council in July 2005, resettlement was introduced as one of the components in the EU Regional Protection Program (RPP) which member countries can implement voluntarily. The RPP increases the ability of communities to deal with refugees with awareness of the need for protection carried out in isolation and they lack local coordination and support from the host government (ECRE, 2013). There are 14 EU member states that actively carry out annual RPPs namely Belgium, the Czech Republic, Denmark, Finland, France, Germany, Hungary, Ireland, the Netherlands, Portugal, Romania, Spain, Sweden and the United Kingdom in the year 2013-2015 (European Resettlement network, 2016). Germany during Merkel's leadership as Chancellor of Germany imposed various humanitarian policies on the Syrian case. German humanitarian policy in Germany's efforts to meet the annual quota given by the RPP program in the International Protection Regime (Fortune, 2015). The RPP regime which requires each of its members to meet an annual quota in accepting refugees is responded positively by Anggela Merkel (European Resettlement Network, 2018). Germany is open to accepting refugees more than 800 thousand refugees from Syria are ready to be accommodated and receive immigrants. The outbreak of Syrian refugees which then made a flow of refugees to Europe, making several European countries not ready and defeat in accepting refugees. So in the European region itself the EU provides the Regional Protection Program - International Protection Regime that has existed since 2005 for the reception of refugees entering Europe (Commission of European Communities, 2005).

The International protection regime in the RPP program is implemented to fulfill quotas in accepting Syrian refugees. But in practice there are some countries that do not enforce quota fulfillment and tend to close the door for Syrian refugees entering their country. So that Germany with Anggela Merkel's leadership style then supports every European regional country to fulfill the quota in refugee reception. Until 2015, only Germany which then faded into accepting Syrian refugees. In the midst of Germany opening and accepting refugees from the Middle East, there has been much condemnation both in Germany and in Europe (Bertelsmann foundation, 2016). Other European countries such as Hungary and Macedonia are trying to close the entrance of immigrants from Syria. European Union member countries in the eastern region, such as Hungary, Poland, the Czech Republic and Slovakia have expressed their refusal to accept refugees.

The German government of Anggela Merkel who was previously committed will continue to open and accept refugees, Merkel will continue to open the door for refugees to enter Germany in the midst of problems that occur and pressure on its policies. However, in Germany due to external pressure both in 2015 Germany reduced refugee reception. The strong drive of the CDU party is a party supporting Merkel pushing to reduce the acceptance of the Syrian crisis refugees in 2015 (Iran Indonesia Radio, 2017). In the same year 2015 many Germans protested and demanded a reduction in refugee reception. The closure of the border of the Balkan countries which was supposed to be the entry point for Syrian refugees from Turkey to the EU was later restrained because the Balkan countries closed the refugee entry paths. So the reduction of refugee acceptance from the admission plan was put in place 
to focus on Germany's regional and domestic stability and cooperation with the Balkan countries was needed for their commitment (Aljazeera, 2017). Germany made various efforts in fulfilling the annual quota in response to the flow of Syrian refugees in 2013-2015. The author uses the 2013-2015 time limit, where in 2013 researchers looked at Syria with a peak flow of refugees from Syria to Europe. So that it gets external and internal demands of Germany itself so that the peak in 2015 Germany began to reduce refugee reception. This is where the effectiveness of the regime's Regional Protection Program (RPP) - the EU International Protection Regime is a big enough question to address the issue of a Syrian crisis amid European countries quarreling with the Syrian crisis coming to Europe.

\section{Literature Review: Concept of Effectiveness of Regimes}

In this study the concept of effectiveness of the regime, which was published in 2002, was used to confirm the issues raised. The concept belongs to Arild Underdal, a political scientist at the University of Oslo, Norway. The regime, according to J. Samuel Barkin, believes that the regime is a behavioral effect of international organizations on other actors, especially on the state. Barkin defines into a set of principles, norms, rules, and procedures in making decisions that are in force around actors who gather in the area where the issue occurs (Barkin, 2005). A regime can also gain ownership rights by making specific rules that limit who owns what and who is responsible for what, forces them, or at least mediates and adjudicates the disputes they face. According to Stephen D. Krasner, the regime is an explicit or implicit collection of principles, norms, regulations, and procedures in decision making where the actors will meet in the scope of international relations. Principles are defined as beliefs from facts, causes, and honesty. Norms as a standard of behavior that is defined in obtaining rights and obligations. Rules are a recipe for making actions. While the procedure for decision making is a general action in making and implementing collective decisions (Krasner, 1982).

While Effectiveness according to experts varies in defining effectiveness. According to Seymour Lipset defines effectiveness as the actual performance of a political system, the extent to which it can fulfill the basic functions of government based on the expectations of the majority of society and interest groups within it (Lipset, 1959). Berlage and Stokke economists, define effectiveness as the ratio of profits flowing from outcomes and costs incurred to get it (Berlage and Stokke, 2007). Underdal in his theory argues that policy makers are faced with the demands of the government's imaging to find solutions to collective problems. Although effective solutions are made and implemented with great effort, cooperation from voluntaries will be more difficult in implementing and enforcing them, it is important to make everyone understand the conditions under which conditions lead to success and failure (Underdal, 2002).

\section{Research Method}

The type of research the author uses in this study is qualitative research with descriptive methods, namely research that answers the question 'how'. Qualitative here the authors conducted a study by collecting data and facts about the effectiveness of the Regional Protection Program (RPP) - International Protection European Union (EU) in Germany 
(Study on Reducing Syrian Refugee Acceptance in 2015). The data collection technique used by the author is library search, which is data collection based on the study of various literatures in the form of books, journals, newspapers, articles, and papers relating to the problem under study.

\section{Discussion}

\subsection{Implementation of the Regional Protection Program (RPP) - International Protection Regime EU (Problem Type)}

Regarding the protection regime has been regulated in COM communication 2004 on "Improving access to Durable Solution" As the EU made an International Protection Regime proposal. Regional Protection Program as a step forward that prioritizes the use of protection capacity from surrounding regions and better protects refugee populations (COMMISSION OF THE EUROPEAN COMMUNITIES, 2005). Protection Oriented as a pilot of the Regional Protection Program, in realizing protection for refugees and the EU region itself.

"... The Regional Protection Program should be carried forward with the intention of enhancing the protection capacity of the regions involved and better protecting the refugee population there by providing Durable Solutions (the three Durable Solutions being repatriated, local integration or resettlement in a third country if the first two Durable Solutions are not possible The Communication also made proposals for the setting up of an EU-wide Resettlement scheme as a means of delivering protection to a greater number of refugees and ensuring a more orderly and managed entry in the EU. ... "(COMMISSION OF THE EUROPEAN COMMUNITIES, 2005)

After confirming the explanation of the information above, it can be seen that the issue of refugee protection focuses on providing long-term protection solutions for refugees and the region. In this study will be confirmed by describing the effectiveness of the regime through the problem type, more precisely based on the indicators in the case study whether malign or benign. Namely by confirming whether coordination or incongruity, symmetry or asymmetry, and cross-cutting cleavages or cumulative cleavages.

\subsection{Coordination Between EU Member States in Dealing With the Syrian Crisis (Incongruity / Coordination)}

The EU grants autonomy to its members in the implementation of the RPP in the implementation of a resettlement of Syrian refugee crisis flows. The annual quota system that has been distributed to members is fulfilled by the law or procedure of each country in implementing refugee reception. Each EU member state has a government that plays an important role in the implementation of the RPP in dealing with the flow of refugees entering Europe to protect the European region from the coming refugee crisis and improve communication and cooperation between EU members. Countries that are under the auspices of the EU, have the right to hold resettlement of Syrians or non-European refugees who are seeking refugee protection. The resettlement of each EU member country to non-EU refugees which is a term used to indicate a temporary country can receive and resettle refugees or asylum seekers who seek protection in the EU region and can protect the EU region from the 


\section{Macrothink}

Journal of Public Administration and Governance

ISSN 2161-7104 2019, Vol. 9, No. 4

threat of the refugee crisis (Pew Research Center, 2015). Three actions included in the Regional Protection Program (RPP) in protecting refugees and European regions from the entry of refugees from non-EU countries include Repatriation, Local Integration, and Resettlement. Repatriation is an attempt to return someone back to their country. This long-term solution is the most so-called safer and more dignified. Local Integration of refugees into the community of host countries that have the prospect of providing legal and autonomous housing.

Table 2. Acceptance of Refugees 2013-2015 EU Member States

\begin{tabular}{|c|c|c|c|}
\hline Time & 2013 & 2014 & 2015 \\
\hline Geo $\nabla$ & & & \\
\hline Belgium & 11.485 & 7.950 & 7.685 \\
\hline Bulgaria & 40 & 20 & 10 \\
\hline Czech Republic & 415 & 565 & 395 \\
\hline Denmark & 1.660 & 1.785 & 1.335 \\
\hline Germany & 36.660 & 44.335 & 93.840 \\
\hline Estonia & 0 & 5 & 10 \\
\hline Ireland & 580 & 210 & 530 \\
\hline Greece & 3.900 & 7.665 & 7.655 \\
\hline Spain & 1.110 & 920 & 580 \\
\hline France & 37.550 & 37.085 & 34.580 \\
\hline Croatia & 95 & 110 & 85 \\
\hline Italy & 95 & 55 & 20 \\
\hline Cyprus & 960 & 495 & 575 \\
\hline Latvia & 55 & 35 & 70 \\
\hline Lithuania & 35 & 15 & 10 \\
\hline Luxembourg & 670 & 740 & 470 \\
\hline Hungary & 685 & 840 & 480 \\
\hline Malta & 140 & 260 & 370 \\
\hline Netherlands & 1.895 & 1.445 & 1.085 \\
\hline Austria & 6.860 & 4.070 & 5.095 \\
\hline Poland & 1.050 & 1.380 & 1.875 \\
\hline Portugal & 100 & 95 & 85 \\
\hline Romania & 1.550 & 170 & 110 \\
\hline Slovenia & 60 & 70 & 35 \\
\hline Slovakia & 115 & 60 & 25 \\
\hline Finland & 230 & 210 & 170 \\
\hline Sweden & 12.685 & 13.130 & 12.765 \\
\hline United Kingdom & 13.685 & 12.310 & 12.430 \\
\hline Iceland & 70 & 30 & 70 \\
\hline Liechtenstein & 35 & 0 & 20 \\
\hline Norway & 10.430 & 9.430 & 4.830 \\
\hline Switzerland & 3.400 & 2.460 & 2.040 \\
\hline Total & 148.575 & 146.950 & 189.340 \\
\hline $\begin{array}{l}\text { European } \\
\text { countries) }\end{array} \quad$ Union $\quad$ (28 & 134.640 & 136.030 & 182.385 \\
\hline
\end{tabular}

During the 2013-2015 period, the use of the EU's International Protection Regime (RPP) was still widely used by EU member states to deal with the Syrian refugee problem. The confirmed EU member who has the highest number in initiating Syrian refugee reception with the EU Regional Protection Program (RPP) in 2015 is Germany, which received 93,840 refugees (EUROSTAT, 2017). 


\section{$\triangle 1$ Macrothink}

Table 3. Table for Filing Refugees

\begin{tabular}{|c|c|c|c|c|}
\hline & Time & 2013 & 2014 & 2015 \\
\hline \multicolumn{5}{|l|}{ Geo $\nabla$} \\
\hline Belgium & & 431.090 & 626.960 & 1.322 .825 \\
\hline Bulgaria & & 21.030 & 22.710 & 44.660 \\
\hline Czech Republic & & 7.145 & 11.080 & 20.365 \\
\hline Denmark & & 695 & 1.145 & 1.515 \\
\hline Germany & & 7.170 & 14.680 & 20.935 \\
\hline Estonia & & 126.705 & 202.645 & 476.510 \\
\hline Ireland & & 95 & 155 & 230 \\
\hline Greece & & 945 & 1.450 & 3.275 \\
\hline Spain & & 8.225 & 9.430 & 13.205 \\
\hline France & & 4.485 & 5.615 & 14.780 \\
\hline Croatia & & 66.265 & 64.310 & 76.165 \\
\hline Italy & & 1.075 & 450 & 210 \\
\hline Cyprus & & 26.620 & 64.625 & 83.540 \\
\hline Latvia & & 1.255 & 1.745 & 2.265 \\
\hline Lithuania & & 195 & 375 & 330 \\
\hline Luxembourg & & 400 & 440 & 315 \\
\hline Hungary & & 1.070 & 1.150 & 2.505 \\
\hline Malta & & 18.895 & 42.775 & 177.135 \\
\hline Netherlands & & 2.245 & 1.350 & 1.845 \\
\hline Austria & & 13.060 & 24.495 & 44.970 \\
\hline Poland & & 17.500 & 28.035 & 88.160 \\
\hline Portugal & & 15.240 & 8.020 & 12.190 \\
\hline Romania & & 500 & 440 & 895 \\
\hline Slovenia & & 1.495 & 1.545 & 1.260 \\
\hline Slovakia & & 270 & 385 & 275 \\
\hline Finland & & 440 & 330 & 330 \\
\hline Sweden & & 3.210 & 3.620 & 32.345 \\
\hline United Kingdom & & 54.270 & 81.180 & 162.450 \\
\hline Iceland & & 30.585 & 32.785 & 40.160 \\
\hline Liechtenstein & & 125 & 170 & 345 \\
\hline Norway & & 55 & 65 & 150 \\
\hline Switzerland & & 11.930 & 11.415 & 31.110 \\
\hline Total & & 21.305 & 23.555 & 39.445 \\
\hline $\begin{array}{l}\text { European } \\
\text { countries) }\end{array}$ & $(28$ & 464.505 & 662.165 & 1.393 .875 \\
\hline
\end{tabular}

While Germany supports Turkey's move by discussing the re-submission of Turkey's membership to the EU and Germany encourages the EU to immediately provide a budget fund of 7 billion Euros to address the Syrian Crisis problem. Until the peak of refugees in 2015 as many as 1,393,875 refugees filed for refugee protection in European countries, especially their destination was Germany which received many refugees. But because of the large influx of refugees and 2015 is the peak of the flow of refugees of many Balkan countries which then closed the refugee entry lane. This is a form of demand for Germany because these countries are afraid of Islamophobia and ISIS issues that are beginning to enter Europe.

From the study in this paper it is concluded, the Syrian refugee crisis problem has a tendency as a malign type problem. Especially by looking at the incongruity of its member countries which illustrates the incongruity indicator between EU member states and Germany in the 
RPP, to its peak at the close of the Balkan lane. But countries coordinated in 2013-2015 and communication before closing the entry point for refugees. This was demonstrated even though with the closure of the Balkan lane German revenue in 2015 was still high. This confirms that the achievement of collective optimum as a condition is desired after the regime.

\subsection{Differences in Interest Between EU Member States in Dealing With the Syrian Crisis}

At the end of 2012, there were at least 28 countries that joined as EU members. Until 2013-2015 there were 28 permanent EU members. Germany itself has been a long-time member of the EU since 1958 and has been a member of the RPP since 2012 after the RPP was then used in dealing with the Syrian crisis (Schengen Visa Info, 2018). One of the main principles in the realization of the RPP is the achievement of good communication and coordination with all members of the RPP which can then become a host country for refugees to then provide security guarantees and resettlement for refugees (Commission of European Communities, 2005).

"... Maximizing the impact of RPPs can be done by assessing where potential gaps may exist and ensuring that additional measures complement and add value to activities (in particularly, humanitarian, and development activities) which are already taking place ..." COM (2005).

To protect the regional EU and enhance cooperation and communication of EU members in the refugee crisis that enters Europe, the RPP provides autonomy for each member of the country with their respective legal systems to fulfill the acceptance quota. Countries that have joined the Regional Protection Program (RPP) - the International Protection Regime European Union (EU) are permitted to take Resettlement and Local intervention actions in dealing with the refugee crisis that enters the European region. As members of the EU, especially Germany, have the same interests to deal with refugee issues and carry out resettlement actions. Here it is concluded that the symmetry between Germany and other EU member countries is already strong enough to see the communication and cooperation that takes place. So, asymmetry is not so visible during the handling of the Syrian crisis problem, although in 2015 there was a closure of the Balkan lane as a form of protest to Germany. The elucidation confirms that there are differences in interests and differences in the distribution of quotas which makes indicators of asymmetry in the practice of lesson plans. In practice the difference of views between the Balkan countries and Germany that triggers the closure of the border by the Balkan Line countries. This difference in outlook is asymmetry. However, despite the closure of the Balkan path by the Balkan countries, European revenues, especially Germany, remained high during the year due to the revenue authority assigned to each member.

\subsection{Divisions Between EU Member States in Addressing the Syrian Crisis}

A problem that is dealt with division is inevitable. Seeing that the EU consists of countries with different capacities, there must be differences in implementing RPP regulations. After there are incongruity and asymmetry indicators, the cumulative cleavages indicator is on the 
malign type problem. This split occurred during the organization of the RPP, which member countries of the EU RPP were used in handling the Syrian refugee crisis case. The high acceptance of Syrian refugees in the 2013-2015 period through the regional protection program shows that there is still good cooperation and communication with other member countries in facing the same interests in dealing with the Syrian refugee crisis. The closure of the Balkan lane by several member countries is a form of coordination and cooperation in stemming the peak flow of refugees which increased in 2015.

This past experience and efforts to change the world view of Germany pushed Merkel in 2013 to receive 36,660 people in Germany (EUROSTAT, 2017). The implementation of political open door to accept refugees who want to get protection from Germany, made a significant increase in acceptance in 2014 , which was 44.335 people which made Germany the most refugee recipient in 2014. The reception then attracted refugees to seek protection and refuge in Germany and other countries. the country that receives the most refugees is Austria. The peak in 2015 the number of refugees entering Europe increased.

A total of 1,393,875 people submitted to enter Europe in 2015, increasing from 2014 to only 662,165 . The increase in the flow of refugees then made the Balkan countries over the large number of Syrian refugees close their borders. This policy of closing the Balkan lane then impacts on the trapping of Syrian refugees on the Balkan and Turkey Lines. Because in 2015 this is the peak flow of refugees. Balkan countries 'concern over the economic crisis and islamophobia Balkan countries' fear of ISIS as well as the acceptance capacity of quotas exceeds the limit. This concern then led to the closure of the Balkan lane which in turn had implications for German revenues less than the proposed quota of 12,225 people in 2015 but until December 2015 Germany only received 93.9840 people. In addition to having an impact on reducing the acceptance of refugees, the closure of the Balkan Line has an impact on Greece which is facing a flow of refugees from Syria.

\subsection{Settlement Capacity of the Regional Protection Program - International Protection Regime of the EU in Dealing With the Syrian Crisis}

Between 2013 and the end of 2015, Germany followed a Regional Protection Program refugee protection strategy specifically oriented towards protection. Solution to the problem of the Syrian refugee crisis has become a polemic towards regional security and the refugees themselves, the influx of refugees in 2011 since the Syrian crisis has pushed the EU to find a long-term solution in resolving the refugee crisis. On 14 June 2004, the EU embodied "Improving Access to Durable Solutions" in realizing the international protection regime with the RPP through the EU Communications Commission. The EU established the Regional Protection Regime - International Protection Regime to increase the capacity of protection for refugees and become a long-term solution by the realization of three long-term solutions, namely Resettlement, Repatriation and Local Integration. In this RPP the EU seeks to increase reception capacity in the protection of refugee populations that enter the EU territory and then to divide the quota of revenues to each country. Through the RPP it provides flexibility and specific situations to consistently realize humanity to increase the protection capacity of third countries. The EU runs a regional protection program - internal protection 
regime because it has two advantages from Resettlement and Local Integration. The first advantage is that the cost of charging refugee protection is lower because it is used in member countries and in the European region.

\subsubsection{EU Capability in Organizing the Regional Protection Program (RPP) - International} Protection Regime

The existence of the EU as a supranational organization consisting of European countries. The EU has an organizational structure that has specific job and function specifications. Not only that, the EU has a government that contains seven institutions namely the European Parliament, the European Union Council, the European Commission, the European Council, the European Central Bank, the European Court and the European Audit Court. The EU has provided facilities and regulations that can be used in the implementation of the RPP. Through the EU Communications Commission on 14 June 2004, the EU embodied "Improving Access to Durable Solutions" in realizing an international protection regime with RPP. The EU established the Regional Protection Regime - International Protection Regime to increase the capacity of protection for refugees and become a long-term solution by the realization of three long-term solutions, namely Resettlement, Repatriation and Local Integration.

The implementation of the RPP requires a host country that acts in accepting refugees and will work with NGOs and non-EU countries or third countries. The EU provides an annual quota for EU Member States which fulfillment is carried out voluntarily because the basis of the RPP itself is as a volunteer. The rules for fulfilling this quota system are stipulated in the RPP, the amount of which is determined by the EU, but the fulfillment of the quota is left to the legal system of each country in its implementation. Grants to implement RPP to every country that implements RPP and receives protection for refugees. These funds are then handed over to each country which is then used in protection activities for refugees. Not only to EU member countries, the funds were given, because the EU also gave Turkey aid funds to facilitate Syrian refugees heading for Europe through Turkey. A total of 4 billion euros in aid was given to Turkey to accommodate refugees from Syria to Europe via the Balkan Line. From this description, it confirms that the Institution as arena where the EU forms the RPP by facilitating each of its members in the implementation of refugee reception. The European Union regulates the RPP for each member to work together in solving problems, regulating the acceptance quota in fulfillment carried out by each country.

4.4.2 Enthusiasm of EU Members Towards the Implementation of the Regional Protection Program (RPP) - International Protection Regime EU (Distribution of Power)

In 2012 since the inauguration of the EU's International Protection Program (RPP), developed and safe countries have always been refugee destinations. Because these countries then receive the most refugees and provide protection capacity for refugees. In fact, the Regional Protection Program has indeed been used since 2005 at AENEAS, which was the initial proposal of the RPP pilots who had previously been in the protection, integration and registration activities of refugees who later became pilots of the RPP (Gozde, 2017). In this AENENAS at least has provided protection to the region of refugees from various countries. 
"... In Convention Plus, the UN High Commissioner for Refugees called for new agreements to supplement the Refugee Convention and help protect refugees and achieve durable solutions in regions of origin. The aim is to use understandings and commitments by States in multilateral agreements that address specific caseloads, including through comprehensive plans of action ... "COM (2005)

EU member countries are very enthusiastic in implementing the RPP in dealing with the Syrian crisis. As it is known that the Syrian refugee crisis problem is a problem faced by European countries. Countries such as Germany, Austria and several countries that see the arrival of refugees with their capacity to receive many refugees. This then encourages cooperation with the state on the Balkan lane which then becomes a path for refugees. This then attracted refugees at their peak in 2015 to Europe to get protection in Germany. Concerns over security due to the rise of ISIS and many countries that have fears of Islamophobia require the Balkan countries to ask Germany to close and stop the acceptance. But Anggela Merkel who remained in her stance accepts refugees because she sees more and more refugees. Germany, which saw the opportunity for acceptance, then accepted more refugees in 2015. However, due to the failed coordination and communication efforts, Balkan countries had to close the border from the arrival of refugees, so that Balkan countries closed the refugee routes that would want to go to Germany.

From the explanation described above, it is concluded that the enthusiasm of the EU countries shows that the EU is a benevolent hegemony, which sees the EU by facilitating the collective needs of other countries. Financial needs for the implementation of refugee protection in carrying out RPP as the main key in seeing actors who are quite dominant. The EU as a benevolent hegemony tends to facilitate its members in providing freedom in accepting refugees. Autonomy given to each country in its implementation, triggers every member to be enthusiastic in its implementation. The autonomy granted allows each member to implement the RPP in accordance with the legal system of each country and can work together with non-EU countries in providing protection capacity for refugees.

4.4.3 Supporting Staff in the Implementation of the Regional Protection Program (RPP) International Protection Regime EU (Skill and Energy)

The existence of the EU, in particular the Regional Protection Program which confirms that it is in accordance with Underdal's statement that the regime will increasingly understand how the system works and must act over time. Seeing that the RPP in which the pilots have been running in 2005 since AENEAS and 2006 in TACIS has made this regime undergo improvement over time. Regional Protection Program (RPP) - The EU International Protection Regime has the skills and energy or supporting staff from non-governmental organizations (NGOs) and non-EU countries. The United Nations High Commissioner for Refugees (UNHCR) cooperates with the EU in developing the Regional Protection Program, which is in line with the EU memorandum of understanding with UNHCR on 15 February 2005, which contains the coordination of the EU, refugees, humanitarian and policy formulation which as a whole covers protection needs covered by impact the refugee population and provide benefits to local communities. 
“...with UNHCR, in line with the Memorandum of Understanding between the Commission and UNHCR of 15 February 2005, and third countries in regions of origin, will necessitate the coordination of EU, refugee, humanitarian and development policies to address the full range of protection needs as well as the impacts of refugee populations on local communities to ensure that benefits are maximized for all. However, humanitarian aid operations in flavor of refugees will not be as such part of the Regional Protection Programs..." COM (2005)

UNHCR is a humanitarian body under the auspices of the United Nations (UN) whose aim is to protect and provide assistance to refugees. UNHCR, which was actively established on December 14, 1950, has the task of handling the Syrian refugee crisis. Through advocacy, assistance, asylum and migration as well as providing sustainable solutions to be able to provide protection for refugees. The existence of the EU in the instrument of leadership that facilitates and funds the organization of the RPP encourages the enthusiasm of EU member states and the support of non-governmental organizations and Turkey which then forms communication and coordination in the protection of Syrian refugees. This confirms the skill and energy characteristics that form an effective regime, these organizations have become a knowledge base, facilitating, and connecting actors who then cooperate with each other in the protection and acceptance of refugees.

From the illustration above shows the settlement capacity of the RPP - the EU International Protection Regime confirms that problem solving capacity tends to lead to problem solving. Encourage an effective or (+) regime in solving problems. Illustrated from the institutional setting, distribution of power, and skill and energy indicators that drive the regime to solve the problem. Institutional setting indicators confirm that there is an institution as an arena in which the EU forms the RPP by facilitating each of its members in implementing refugee reception. Encourage each member to implement the RPP in providing protection capacity for refugees. The EU arranges for each of its members to then cooperate in solving problems and regulating the quota for refugee reception.

The autonomy granted allows each member to implement the RPP in accordance with the legal system of each country and can work together with non-EU countries in providing refugee protection capacity. The skills and energy indicators confirm the existence of the EU in the leadership instrument which facilitates and finances the organization of the RPP encourages the enthusiasm of EU member states and the support of non-governmental organizations and Turkey which then forms communication and coordination in protecting Syrian refugees. This confirms the characteristics of skills and energy that form effective regimes, these organizations have become a knowledge base, facilitates, and connects actors who then cooperate with each other in the protection and acceptance of refugees. The above description confirms that problem solving capacity leads to problem solving which encourages an effective regime, the next the authors analyze based on the level of collaboration in interning variables through a scale of 6 ordinate skills that will confirm at what level of cooperation between EU members in the implementation of the RPP International Protection Regime. Then the authors analyze the effectiveness of this regime in the dependent variable to see its effectiveness. 
4.5 Collaboration Level Implementation of the Regional Protection Program (RPP) International Protection Regime EU (Level of Collaboration)

Through one of the six-point ordinal scale from the level of collaboration, the authors see the problem type and problem-solving capacity refers to the level of collaboration or cooperation at level 2. Ie "Coordination of action on the basis of explicitly formulated rules or standards but with implementation. fully in the hands of national government. No centralized appraisal of the effectiveness of measures is undertaken ", or the existence of coordinated planning based on the formulation of standard regulations but with the implementation of the full implementation in the hands of the national governments of each member country. There is no centralized assessment of the effectiveness measures taken. The assessment is based on two variables in the Independent variable (problem type and problem-solving capacity). After learning that problem-solving capacity with conditions that tend to describe the achievement of collective optimum so that as an institution that forms a regime, the EU is considered to have the capacity to implement regulations and handle refugee crisis issues. Although the Regional Protection Program (RPP) in Germany with a case study of German revenue reduction in 2015 and has a malign type problem that confirms the characteristics of incongruity, asymmetry, and cumulative cleavages.

This RPP then gives autonomy to the acceptance of refugees to each EU member country, this aims to protect the regional EU from the refugee population that comes. The RPP provides an annual quota policy in accepting refugees which is expected that each member is willing to fulfill the quota with the policies and methods of each member of the country. From this description, it is confirmed that the level of collaboration of the EU in the six-point ordinal is at level 2. Where in the implementation of the RPP there is coordination based on the formulation of standard regulations but the implementation of the full RPP is in the hands of the national government due to the presence of the EU authority in the implementation of the RPP. There is no centralized assessment of the implementation and implementation of the effectiveness carried out, so that many quota fulfillments are not required to be fulfilled because the basis of the RPP is voluntary basic.

4.6 Analysis of the Effectiveness of the Regional Protection Program (RPP) - International Protection Regime in Dealing With the Syrian Crisis (Regime Effectiveness)

Incongruity indicators, confirm that the implementation of the Regional Protection Program (RPP) - International Protection Regime in dealing with the Syrian crisis problem, EU member countries have differences in viewing the Syrian crisis and the preference to use the RPP as a solution. This is evidenced by the use of the Regional Protection Program (RPP) International Protection Regime whose use is confirmed by the existence of the Balkans who closed the border door for refugees in the study of the reduction of refugee acceptance by Germany in 2015. This case study is due to the economic crisis faced by several countries and as a form of communication of the Balkan countries to Germany. As such, EU member states illustrate the lack of coordination and synergy over the implementation of the International Protection Regime (RPP).

Germany made a large contribution to the sustainability of the regime by fulfilling the quota 
and active participation in inviting other members to fulfill the RPP quota. Germany adopted the RPP since the 2013 Syrian refugee crisis entered Europe, and in 2015 finally reduced refugee acceptance. But its acceptance exceeds other EU countries. From the implementation of the RPP, Germany received support from German law in accepting refugees and did not forget the leadership factor of Anggela Merkel who was so straight in implementing the RPP. Germany's good step by opening its wide door for refugees was then positively responded by UNHCR who helped Germany in the implementation of the resettlement, Turkey's role as a refugee transit country to Europe became a form of support for the implementation of the RPP by Germany.

For technical optimum, based on the achievements obtained from the problem type, problem-solving capacity, along with the level of collaboration, it has been shown that technical implementation in this regime is good enough to indicate the existence of an ideal or effective solution (collective optimum). Especially, with problem types that tend to be malignant, the achievement of protection and acceptance of Syrian refugees with the Regional Protection Program (RPP) and a high level of collaboration or cooperation at level 2. Thus, the Regional Protection Program (RPP) - the International Protection Regime EU can be said as an effective regime in dealing with refugee crisis issues, especially in Germany in 2015 .

\section{Conclusion}

From the results of this study, it was confirmed that this regime was effective in resolving the problems of the Syrian refugee crisis in Germany in 2015. Even though the problem was malignant, seeing the still high acceptance of refugees by EU countries in 2015 indicated that it was aimed at being effective although difficult. Problem Solving which leads to the effectiveness of the regime and the achievement of Technical Optimum. In the Level of Collaboration this regime is at level 2 which then results in different collaboration and collaboration at the country level.

From the behavioral change of EU member states in the presence of refugees and the presence of various efforts against Syrian refugees from each EU RPP member state. This shows that there is a change in the behavior of actors in the EU to implement the Regional Protection Program (RPP) - International Protection Regime in accepting Syrian refugees, many countries joining the Regional Protection Program (RPP) - International Protection, especially EU countries, want to implementing and accepting refugees although in practice some Balkan countries have begun to close down to reduce the entry of Syrian refugees into Europe.

Seen also the problem of the Syrian crisis in Germany in problem-solving capacity consisting of institutional settings, distribution of power, and skills and energy, confirming that the International Protection Regime (EU) regime's Regional Protection Program (EU) is effective in dealing with refugee reception Syria. European Union (EU), as one of the supra-national organizational entities, has been quite successful in organizing the International Protection Regime (RPP) in responding to the Syrian crisis. 
On the one hand, if you see the increasing number of Syrian crisis refugees in Europe, illustrating that this RPP regime with resettlement measures is strong enough to overcome the influx of the refugee crisis. The implementation of the RPP that is entirely in the member countries makes the level of collaboration worth 2. The impact is, the increasing number of refugees entering the EU makes some countries over capacity, the economic crisis and the boom make member countries dependent on countries that receive the most refugees. So that refugees are not detained in an area like when the Balkan door closes for refugees in 2015.

But disputes cannot be avoided by the issue of ISIS and Islamophobia, some countries have made concerns over the large number of refugees, so that the Balkan countries are trying to close their borders as a form of communication to the most recipient countries in order to reduce acceptance. For example, a country that focuses on revenue such as Germany, which has done a lot of resettlement actions and received demands from the Balkans by closing the path to Germany in 2015.

Whereas Behavioral change can be seen from the outcome in which there is a change in attitude towards the existence of the RPP where Germany accepts more refugees, the Balkan states split after this RPP is implemented and increases the acceptance and interest of Syrian refugees heading for Europe. The achievement of Technical Optimum based on the achievements obtained from the problem type, problem-solving capacity, along with the level of collaboration, has shown that the optimum collective has not been achieved properly. Especially, with problem types that tend to be malignant. The achievement of protection and acceptance of Syrian refugees with the Regional Protection Program (RPP) and a high level of collaboration or cooperation at level 2. Thus, the Regional Protection Program (RPP) - the EU International Protection Regime can be said to be an effective regime in dealing with refugee crisis issues, especially in Germany in 2015.

\section{References}

Aljazeera. (2017). 'Control' is the new core of Germany's refugee policy. Accessed from, http://www.aljazeera.com/indepth/opinion/2017/03core-germany-refugee-policy-1703020730 29337.html on April 20.

Barkin, J. S. (2005). International Organization: Theories and Institution. Newyork: Palgrave Macmillan.

Stokke, O. S. (2007). Determining the Effectiveness of International Regimes. Svt. Ntnu. No.

Bertelsmann foundation. (2016). Germany's Respone to the Refugee Situation. Remarkable Leadership or Faith Accomplish accessed from http://www.bfna.org/publication/newpolitik/germanys-response-to-the-refugee-situation-rema rkable-leadership-or-fait-accompli on (October 12, 2018).

Commission of the European Communities. (2005). Communication From The Commission To The Council And The European Parliament On Regional Protection Programes. Brussles [PDF]. Accessed from, http://www.refworld.org/pdfid/43e203ed4.pdf on (January 20, 2019).

ECRE. (2013). Regional Protection Program: an Effective policy tool ?, accessed from, 
http://www.ecre.org/regional-protection-programmes-an-effective-policy-tool/ on (October 05, 2018).

European Commission. (2012). Migration and Home Affairs, accessed from the website http://ec.europa.eu/dgs/home-affairs/what-we-do/policies/asylum/external-aspects/index_en.h tm on (05 October 2018).

European Resettlement network. (2018) Introduction to Resettlement in Europe, Resettlement and The European Asylum System, accessed from the website http://www.resettlement.eu/pageintroduction-resettlement-europe on October 5.

European Resettlement Network. (2016). Regional Protection Program, Regional Development and Protection Program (RDPP) in the Middle East, accessed from the website http://www.resettlement.eu/page/introduction-resettlement-europe on (October 05, 2018)".

Fortune. (2015). What Angela Merkel's New Refugee Policy Misses. Accessed from http://fortune.com/2015/12/20/angela-merkel-migrants-syria/ on (October 1, 2016).

Global Living Foundation. (2015). Syrian Refugee Relief Fund. Accessed from https://www.globalgiving.org/projects/syrian-refugee-relief-fund/?gclid=CjwKEAiA_9nFBR Csurz7y_Px8xoSJAAUqvKC9D112ngOiBi6IK0EjSNOGwLm

Gozde, A. Y. (2017) The European Union's immigration policy. Yasar University: Turkey. Accessed from Google books through the website https://books.google.co.id/books?id=0JzVDAAAQBAJ\&pg=PA75\&lpg=PA75\&dq=rule+regi onal+protection+program+eu\&source=bl\&ots=cQlkoT61EW\&sig=R-myRA462qefHztm6tli OrAChqx \&hl=en\&id=id= rule $\% 20$ regional $\%$ 20protection $\% 20$ program $\%$ 20eu $\& \mathrm{f}=$ false on May 13.

Iran Indonesian Radio. (2017). Merkel Decides to Reduce the Number of Refugees in Germany. Accessed from http://indonesian.irib.ir/international/eropa/item/104228-merkel-pututus-kotal-pengungsi-di-j erman on April 20.

Krasner, S. D. (1982). International Organization / Volume 36. (1982). [PDF]. Accessed via: http://ir.rochelleterman.com/sites/default/files/krasner\%201982.pdf on February 12, 2019.

Lipset, S. M. (1959). Some Social Requisites of Democracy: Economic Development and Political Legitimacy. The American Political Science Review. https://doi.org/10.2307/1951731

Pew Research Center. (2015) Number of Asylum seekers in Europe surges to record 1.3 million in (2015). Accessed from http://www.pewglobal.org/2016/08/02/number-of-refugees-to-europe-surges-to-record-13-million-in-2015 / pgm_2016-08-02_europe-asylum-01-01 / on June 12, 2019.

Schengen Visa Info. (2018). EUROPEAN UNION. Accessed from, https://www.schengenvisainfo.com/eu-countries/ on March 12, 2019. 


\section{Macrothink}

Journal of Public Administration and Governance ISSN 2161-7104 2019, Vol. 9, No. 4

Underdal, A. (2002). One Question. Two Answers. Cambridge: MIT Press. [PDF]. Accessed via https://mitpress.mit.edu/sites/default/files/titles/content/9780262632416_sch_0001.pdf on (February 12, 2018).

UNHCR. (2018) Refugees, accessed from the website http://www.inhcr.or.id/id/who-yang-kami-bantu/pengungsi on October 1.

UNHCR. (2019) History of UNHCR. Accessed from http://www.unhcr.org/history-of-unhcr.html on June 20.

UNHCR. (2018) Temporary humanitarian admission program for Syrian refugees (THAP). [PDF].

Accessed

via

http://www.unhcr.de/fileadmin/user_upload/docse/02_unhcr/thap2013e.pdf on March 26.

\section{Copyright Disclaimer}

Copyright for this article is retained by the author(s), with first publication rights granted to the journal.

This is an open-access article distributed under the terms and conditions of the Creative Commons Attribution license (http://creativecommons.org/licenses/by/4.0/). 